\title{
march of dimes/colonel harland sanders award
}

Through its Colonel Sanders Memorial Campaign, established in 1979, Kentucky Fried Chicken has contributed more than $\$ 5.5$ million toward March of Dimes programs to prevent birth defects.

In 1986, the March of Dimes sponsored the first award for lifetime achievement in research and education in the genetic sciences. The award is presented during the March of Dimes portion of the Annual Clinical Genetics Conference.

The March of Dimes is proud to announce the presentation of the 2000 March of Dimes/Colonel Harland Sanders Award for lifetime achievement in the field of genetic sciences to:

\author{
Michael M. Kaback, MD \\ Children's Hospital \\ University of California, San Diego
}

The presentation will take place on Saturday, March 11, from 4:45 pm-5:15 pm in the Oasis 2 Room of the Palm Springs Convention Center.

\section{Previous Award Recipients}

1999 - Barton Childs, MD

1998 - James V. Neel, MD

1997 - David L. Rimoin, MD, PhD

Charles R. Scriver, CC, MDCM,

1996 - Arno G. Motulsky, MD

1995 - Charles J. Epstein, MD

1994 - Judith G. Hall, MD

1992 - Arthur Robinson, MD

1991 - John M. Opitz, MD

1990 - Hans Zellweger, MD, FRS, FRSC

1989 - Robert J. Gorlin, DDS, MS, DSc

1988 - Victor A. McKusick, MD

1987 - F. Clarke Fraser, MD, PhD, DSc

1986 - Joseph Warkany, MD, DSc 